\title{
Nonprofit Organizations in the Knowledge Based Economy - Organizational Development and Professionalization
}

\author{
Katalin Dobrai, Ferenc Farkas \\ Faculty of Business and Management, University of Pecs, Hungary
}

\begin{abstract}
International research results underpin that turbulent, continuously changing environment makes everyday operations for nonprofit (nongovernmental, voluntary) sector organizations harder. It also can be observed that in this situation, nonprofit organizations acquire knowledge from business sector organizations which enables them to improve their structures and processes. They implement methods of the business sector as means of ensuring long term existence, better performance and sustainable success. In recent years, this process has generated new dilemmas for those who are concerned with the future of this sector: if and how the strengthening focus on knowledge processes such as learning and development of individuals working for nonprofit organizations impact organizational knowledge and organizational development and, how important professionalization is for them.

The goal of this paper is, to give an overview of special issues of learning and growing professionalization of non profit organizations, and to contribute to the research of these processes. Empirical evidence is provided on the base of a large sample survey that involves approximately 1.000 Hungarian foundations or associations. With the help of the research findings the paper shall expand our general knowledge about professionalization trends in the sector, and also provide deeper insight in details of the relationship between participation in organizational development programs and becoming more professional in everyday operations and services.
\end{abstract}

Keywords: nonprofit organizations, learning, professionalization, knowledge, development

JEL classification: L30, 015

Acknowledgments: The authors are grateful to the Hungarian Scientific Research Fund project No. 101886 for supporting the research "Knowledge based services professionalization of nonprofit organizations", presented in the paper. The present paper is dedicated to the 650th anniversary of the foundation of the University of Pécs, Hungary.

\section{Introduction}

Research results prove that the changing environment makes everyday operations for nonprofit (nongovernmental, voluntary) sector organizations more and more challenging, sometimes even difficult (Salamon, 2012). This goes along with a variety of changes within nonprofit organizations, such as organizational changes, changes in leadership and organizational processes (Ebrahim et al. 2014; Epstein and McFarlen, 2011). In this situation, they have to learn constantly: so they acquire knowledge from business sector organizations (Chen and Graddy, 2010; Kreutzer, 2009) which enables them to use models and solutions, and to implement methods 
of the business sector for long term existence, better performance and sustainable success (Al-Tabbaa et al., 2014; Mannsky and Siebart, 2010).

In recent years, new dilemmas arose for those who are involved with this sector. They focus on knowledge processes such as learning and development of individuals working for nonprofit organizations and their impact on organizational knowledge, and organizational development and in connection with that, the importance of professionalization for individual and organization.

The aim of this paper is, to give overview over special issues of learning and growing professionalization of non-profit organizations, from both theoretical and practical perspectives. It focuses will be on one hand, on the relationship between learning and developing skills, and on the other hand, between a growing professionalization of their activities. Empirical evidence is provided on the base of a large sample survey carried out about and with the participation of Hungarian nonprofit organizations. In Hungary - except for the last 3 years - the number of organizations and their impact is growing (Statisztikai Tükör/Statistical Mirror, 2014), similarly to worldwide trends. Although the research in this field had started years earlier, this general decline during the last years has drawn the authors' attention even more than earlier to the fact that sustainable existence of the organizations of the nonprofit sector to a large extent depends on their development. The paper shall be a contribution to a better understanding of learning and development features of nonprofit sector organizations.

In correspondence with the aims of the paper, it first analyses some relevant theoretical aspects of the professionalization in the nonprofit sector. We use mainly the international research of the last decade focusing on issues of the professionalization of the nonprofit organizations. After the analysis of literature, the research methodology is introduced, followed by the analysis and discussion of the empirical research about the non-profit organizations from the perspective of the trends that are studied in the desk research. The paper concludes with lessons learned from the research and the limitations of research and also highlights further research ideas.

\section{Background Literature}

Because of the term 'nonprofit organizations' is used in different meanings it is necessary to declare that we accept the definition of Salamon and Anheier (1992) according to which nonprofit organizations as entities that are institutionalized, and have regularity in their activities; are private, independent from the government, even if they receive support from the government; don't distribute profits to their owners or leaders but reinvest their surplus earnings into the objectives of the organizations; are not controlled by other entities from outside the organization; and membership or participation in the activities is voluntary.

\section{Approaches to Professionalization}

Professionalization in the nonprofit organizations can be understood as the implementation of business strategies, the usage of methods and tools that help them become market-oriented (Mannsky and Siebart, 2010). Various professionalization types are known in literature showing different concepts and foci such as organizational professionalization, systemic professionalization, occupational professionalization (Dowling et al., 2014), or managerial professionalization (Salamon, 2012). 
Practice-oriented publications such as De Vita et al. (2001) or Callanan et al. (2014) address the aspects of professionalism by providing help to nonprofit leaders: Callanan et al.(2014) found that deficiencies exist in most leadership fields and identified basically each of the fields of activities as areas of intervention. Neff and Randall (2011), and also Green and Hauser (2012)argue for talent focus in nonprofit organizations as a way to be able to professional performance.

Professionalism from the perspective of organizational change means leadership focusing on participation and autonomy of the employees. From the perspective of human resources, characteristic of it is the usage of formal and supporting processes, the need of training and development, and performance evaluation (Farkas, 1995). The professionalization as a change process is a process of change from nonprofessional to professional people working for the nonprofit organization.

We understand under professionalization the process of becoming professional: the process of developing high level of professionalism. It means not being an amateur any more, showing expertise, professionalism of fulfilment of both organization related tasks and of internal and external services.

\section{Changing Organizational Structures - New Ways of Operation}

It is increasingly characteristic of the sector that along with the traditional nonprofit organizations also new legal forms are emerging, among others, also hybrid forms. Hybrid organizations are organizations possessing characteristics of organizations of more than one sector (Billis, 2010; Davie, 2011; Strečansky and Stoláriková, 2012) and systematically integrating civil society and markets (Jäger and Schröer, 2014). They use governance and operational methods and technics of different organizational types parallel; and are characterized by improving business mindset.

Their emergence is a sign of the dynamism and resilience of the sectors organizations (Salamon, 2012) and it means the new solutions, and new opportunities such as accessing social networks and other structures that are formalized and bring professionalized knowledge in the organizations. This phenomenon is at the same time a tendency that goes along with the implementation of different governance methods and techniques (Wellens and Jegers, 2013; Arsenault, 2004). A variety of situational factors have an impact on the solutions, on managerial or governance tools and their introduction and practice at the different organizations (Kreutzer, 2009; Epsteinand McFarlen, 2011). A Unique governance challenge that raises learning needs is the governance of social enterprises (Ebrahim et al., 2014), since there is a double accountability situation for them, for fulfilling their social mission and for making profit.

Also cross-sectoral collaboration is a topic that is addressed in connection with organizational learning (Chen and Graddy, 2010; Cousins et al. 2014). Researchers find that examination of these co-operations from the point of view of nonprofit organizations is still lacking(Al-Tabbaa et al., 2014), although co-operational forms are beneficial for both of the partners. This co-operation goes along also with crosssectoral mobility, and experts coming from the business sector are carriers and transferors of business knowledge in the non-profit sector (Epstein and McFarlen, 2011).

Organizational development as "the system-wide application and transfer of behavioral science knowledge to the planned development, improvement, and reinforcement of the strategies, structures, and processes that lead to organization effectiveness" (Cummings et al., 2008: 752), is also viewed as a mean of professionalization and capacity building (McKinsey \& Company, 2001). The choice 
how to develop the different capacities depends on the interest of stakeholders for they have in connection with capacity building different preferences and also different reasons to support organizational development initiatives (Millesen et al., 2010).Fields where OD is necessary is non-profit organizations include people carrying out the projects, leaders, staff and organization leaders, even donors and projects (Tschirhart and Bielefeld, 2012). We view organization development a sa top-down effort that involves the whole organization and aims at increasing the efficiency and the lifecycle of an organization by taking structured actions.

The briefly highlighted structures and processes, together with people, construct the three basic constituents of the professionalization of nonprofit organizations (Dobrai and Farkas, 2013). "Structures" such as hybrid forms, networks, knowledge communities, project teams can be considered as more effective structures then the traditional forms. As for "people", the importance of professional knowledge is growing in functional areas and also in leadership and management (competence improvement, improving educational level, skills, learning culture, professional volunteers etc.).Among "processes" we can mention the implementation and usage of management tools, the implementation of management techniques, introduction of new and better solutions, networking, co-operation, and organizational development.

\section{Methodology}

The next sections of the paper provide a brief summary and analysis of the empirical research .In order to answer the research question: "Is organization development a suitable tool for promoting and enhancing the professionalization of nonprofit organizations?" we used different research methods during the different phases (Table 1).

Table 1

Main Phases of the Research and Methods Used

\begin{tabular}{|c|c|c|c|}
\hline $\begin{array}{c}\text { Research } \\
\text { Phase }\end{array}$ & Methods Used & $\begin{array}{c}\text { Number of } \\
\text { Organizations } \\
\text { Involved }\end{array}$ & $\begin{array}{c}\text { Location of } \\
\text { Organizations Involved }\end{array}$ \\
\hline Phase 1 & questionnaire & 33 & 2 counties \\
\hline Phase 2 & interviews & 38 & 2 counties \\
\hline Phase 3 & questionnaire & 841 & countrywide \\
\hline Phase 4 & interviews & 41 & countrywide \\
\hline
\end{tabular}

Source: created by the authors

The empirical research started in 2011-2012, with a pilot project including two counties of Hungary. An online questionnaire was sent to 58 participants of an organizational development program at the House of Civil Communities in Pécs, and returned by 33 organizations. In the next phase semi-structured interviews were made with representatives of 38 organizations, most of them participants of the online survey. In the third phase (2013) a large sample survey took place that used the experiences of the previous phases, and the database of the Central Statistical Bureau of Hungary. 18000 thousand questionnaires were sent to organizations via email. 841 questionnaires were returned. We also made 41 additional interviews in the last research phase with organizations from different regions of the country.

This article summarizes the findings that answer the following hypotheses: 
H1. A significant difference can be observed in the level of professionalism between the organizations that have already participated in OD programs and those organizations that have not taken part in such programs.

H2. Organizational development programs help the professionalization of nonprofit organizations.

H3.Theorigin of the service provider has an impact on the level of satisfaction with the OD program.

H4. There is a connection between the perceived professionalization level of the respondent, and that of his/her perception of the organizational level of professionalization.

H5. The differences perceived in the personal and organizational professionalism show tight correlation.

With the help of descriptive statistics, associations, and correlation analysis, the statements in this paper provide an analysis of the responses to the questionnaire of the third phase that focused on organization development and professionalization. Some parts of it were adjusted also to organizations that had not participated in focused OD programs. Most of the questions were 7-point Likert-type scale questions.

\section{Results and Discussion of the Empirical Research}

The analysis of the relationship between personal and organizational professionalization (Table 2) shows that

- those respondents who had earlier participated in OD programs gave their own professionalization level, on a 7-point scale, an average score of 4,78, and placed the professionalization level of their organization somewhat lower, with an average score of 4,62; whereas

- those who had never participated in an OD program, perceived the two professionalization levels as being much lower: 3,60 for individual and 3,41 for organization, respectively. $(\mathrm{H} 1)$

This result was also supported by correlation analysis that pointed out a positive relationship between participation in an $O D$ program and the perceived professionalization level. $(\mathrm{H} 2)$

Table 2

Relationship between the Participation in an OD Program, and the Perceived Level of Professionalization (7-Point Scale, Mean)

\begin{tabular}{|c|c|c|}
\hline $\begin{array}{c}\text { Participation in OD } \\
\text { Program }\end{array}$ & \multicolumn{2}{|c|}{ Evaluation of Professionalization (7-Point Scale) } \\
\hline Participated & Individual & Organization \\
\cline { 2 - 3 } & 4,78 & 4,62 \\
\hline Did not participate & 3,60 & 3,41 \\
\hline
\end{tabular}

Source: created by the authors

The hypothesis regarding the impact of the program provider's origin on the satisfaction with the program was also verified (Table 3): according to the research findings, it also depends on the provider of the OD program how efficient the participants find an OD program. Although there isn't a big difference between the averages of the three categories, those who had participated in an EU-supported OD program found that they had reached a high level of professionalism, and the least satisfied were the participants of domestic programs (H3). 
Table 3

Connection between the Provider of the OD Program and the Perceived Level of Professionalization (7-Point Scale, Mean)

\begin{tabular}{|c|c|c|}
\hline $\begin{array}{c}\text { Origin of the Organization } \\
\text { Providing the OD Program }\end{array}$ & $\begin{array}{c}\text { Level of Personal } \\
\text { Professionalism }\end{array}$ & $\begin{array}{c}\text { Level of Organizational } \\
\text { Professionalism }\end{array}$ \\
\hline Hungary & 4,67 & 4,50 \\
\hline EU & 5,03 & 4,81 \\
\hline Foreign & 4,87 & 4,87 \\
\hline
\end{tabular}

Source: created by the authors

Regarding personal and organizational professionalization level, we can say that for their own personalization level, respondents gave on the average, the score 3,93 and gave their organization regarding professionalization level an average score of 3,75 . Skewness and kurtosis show normal distribution in both cases.

Research data also show that the higher the perceived level of the personal professionalization is, the higher is the perceived level of organization professionalization (Pearson correlation: ,753**, Sig. (2-tailed) ,000, ** strong and positive relationship. $(\mathrm{H} 4)(\mathrm{H} 5)$.

Observing the connection between the professionalization level of the organization and the age of the organization, we can see that those organizations reached the highest professionalization level $(4,10)$ that had been operating for 9-15 years. The lowest level was characteristic of organizations that had existed for 1-3 years $(2,88)$. The difference between these values also supports the hypothesis about the connection between age, development and professionalism both at individual and organizational level.

\section{Conclusion}

Through literature and the example from the practice, the article provides evidence of the fact that nonprofit organizations feel the importance of organizational development from the perspective of their sustainable existence.

As survey results prove, the OD programs fit each of the participating organizations and programs fitted to the special needs of the different organizations. They helped them learn and improve their skills and knowledge, and to become more professional in their service. The findings support our hypotheses hat OD programs and OD provider influence the subjective professionalization level of the individual and of organization, and that there is a tight positive relationship between personal and organizational professionalism. The hypotheses were verified and the answer to the research question is "Yes": organization development a suitable tool to promote and enhance professionalization of nonprofit organizations.

This paper contributes to the knowledge of the professionalization in the nonprofit sector not only in Hungary, but also in other post-socialist countries (Korolczuck, 2014; Epperly and Lee, 2015; Strečansky and Stoláriková, 2012; and Dill, 2014), and as a result of this, help their Western counterparts to see development in this region. However as a limitation of this research we should mention a limited comparability of it with the research in other countries. This is a possible expansion of the research in the future internationally, along with an expanded and deep analysis of the interviews of Phase 4. 


\section{References}

1. Al-Tabbaa, O., Leach, D., March, J. (2014), "Collaboration between Nonprofit and Business Sectors: A Framework to Guide Strategy Development for Nonprofit Organizations", Voluntas, Vol. 25 No. 3, pp. 657-678.

2. Arsenault, P. M. (2004), "Leadership Assessment and Development”, in: Riggio, R. E., Smith Orr, S. (eds.), Improving Leadership Nonprofit in Nonprofit Organizations, Jossey-Bass, San Francisco, pp. 252-266.

3. Billis, D. (2010), "From welfare bureaucracies to welfare hybrids",in Billis, D. (ed.), Hybrid Organizations and the Third Sector: Challenges for Practice, Theory and Policy, Palgrave Macmillan, London, pp. 3-24.

4. Callanan, L., Gardner, N., Mendonca, L., Scott, D. (2014),"What social-sector leaders need to succeed", Insights Publications, November, 1-10, available at: http://www.mckinsey.com/insights/social_sector/what_social_sector_leaders_need_to_su cceed (accessed November 14 th 2014).

5. Chen, B., Graddy, E.A. (2010), "The Effectiveness of Nonprofit Lead-Organization Networks for Social Service Delivery", Nonprofit Management and Leadership, Vol. 20 No. 4, pp. 405-422.

6. Cousins, J.B., Goh, S.C., Elliott, C., Aubry, T., Gilbert, N. (2014), "Government and voluntary sector differences in organizational capacity to do and use evaluation", Evaluation and Program Planning, Vol. 44, pp. 1-13.

7. Cummings, T.G., Worley, C.G. (2008), "Organization Development \& Change", SouthWestern Cengage Learning, Mason, USA.

8. Davie, G. (2011), "Social Entrepreneurship: A Call for Collective Action", OD Practitioner, Vol. 43 No. 1, pp. 17-23.

9. De Vita, C. J., Fleming, C. (eds.) (2001), "Building Capacity in Nonprofit Organizations", The Urban Institute, Washington D.C.

10. Dill, A.P. (2014), "Health Care and Disability NGOs in Croatia: State Relations, Privatization, and Professionalism in an Emerging Field", Voluntas, Vol. 25 No. 5, pp. 1192-1213.

11. Dobrai, K., Farkas F. (2013), "Organizational Development: A Tool for Nonprofit Organizations to Become Professional", International Journal of Management, Knowledge and Learning, Vol. 2 No. 1, pp. 45-64.

12. Dowling, M., Edwards, J., Washington, M. (2014), "Understanding the concept of professionalisation in sport management research", Sport Management Review, 17, pp. 520-529.

13. Ebrahim, A., Battilana, J., Mair, J. (2014), "The governance of social enterprises: Mission drift and accountability challenges in hybrid organizations", Research in Organizational Behavior, Vol. 34, pp. 81-100.

14. Epperly, B., Lee, T. (2015), "Corruption and NGO Sustainability: A Panel Study of Postcommunist States", Voluntas, Vol. 26 No. 1, pp. 171-197.

15. Epstein, M.J., McFarlan, F.W. (2011), „Nonprofit vs. For-Profit Boards. Critical Differences”, Strategic Finance, pp. 28-35.

16. Farkas, F. (1995), "A modern menedzsment elemei a nonprofit szektor szervezeteiben" (Elements of Modern Management in the Organizations of the Nonprofit Sector), Nonprofit Kutatóközpont Egyesület, Pécs-Budapest.

17. Green, A., Hauser, J. (2012), "Managing to Change the World. The Nonprofit Manager's Guide to Getting Results", Jossey-Bass, San Francisco.

18. Jäger, U.P., Schröer, A. (2014), "Integrated Organizational Identity: A Definition of Hybrid Organizations and a Research Agenda", Voluntas, Vol. 25 No. 5, pp. 1281-1306.

19. Korolczuk, E. (2014), "Promoting Civil Society in Contemporary Poland: Gendered Results of Institutional Changes", Voluntas, Vol. 25 No. 4, pp. 949-967.

20. Kreutzer, K. (2009), "Nonprofit Governance during Organizational Transition in Voluntary Associations", Nonprofit Management and Leadership, Vol. 20 No. 1, pp. 117-133.

21. Mannsky, A., Siebart, P. (2010), "Trends der Professionalisierung in NonprofitOrganisationen", PWC, Frankfurt am Main, available at: https://www.pwc.de/de DE/de/offentliche- 
unternehmen/assets/Trends_der_Professionalisierung_in_Nonprofit-Organisationen.pdf (accessed October 17th 2014)

22. McKinsey \& Company (2001), "Effective Capacity Building in Nonprofit Organizations, prepared for Venture Philantrophy http://research.urban.org/UploadedPDF/building_capacity.PDF (accessed September 20th 2013)

23. Millesen, J.L., Carman, J.G., Bies, A.L. (2010), "Why Engage? Understanding the Incentive to Build Nonprofit Capacity", Nonprofit Management and Leadership, Vol. 21 No. 1, pp. 5-20.

24. Neff, D.J., Randal C. (2011), "The Future of Nonprofits: Innovate and Thrive in the Digital Age", John Wiley \& Sons, Inc., Hoboken, New Jersey.

25. Salamon, L.M. (ed.) (2012), "The State of Nonprofit America", Brookings Institution Press, Washington D.C.

26. Salamon, L.M., Anheier, H.K. (1992), "In Search of the Nonprofit Sector II: The Problem of Classification", The Johns Hopkins University Institute for Policy Studies, Baltimore.

27. Statisztikai Tükör (Statistical Mirror) (2014), "A nonprofit szektor legfontosabb jellemzői, 2013" ("The most important characteristics of the nonprofit sector, 2013"), Statisztikai Tükör (Statistical Mirror), No. 142, December, 19, Központi Statisztikai Hivatal. (Central Statistical Bureau of Hungary), pp. 1-4.

28. Strečansky, B., Stoláriková, K. (2012), "Social Economy and Social Enterprises in Slovakia", Civil Szemle, Vol 9 No. 4, pp. 87-100.

29. Tschirhart, M., Bielefeld, W. (2012), "Managing Nonprofit Organizations", John Wiley \& Sons, Inc., Hoboken, New Jersey.

30. Wellens, L., Jegers, M. (2013), „Effective governance in nonprofit organizations. A literature based multiple stakeholder approach", European Management Journal, pp. 121.

\section{About the authors}

Katalin Dobrai is an associate professor at the Faculty of Business and Economics at the University of Pécs. Her main teaching areas include Leadership and management and Knowledge management. Her research focuses on knowledge management and organizational learning in knowledge-intensive businesses, and nonprofit organizations. She has participated in several research projects funded by the Hungarian government and the European Union.

Author can be contacted at dobrai@ktk.pte.hu

Ferenc Farkas is a full professor at the Faculty of Business and Economics at the University of Pécs. His teaching areas include change management, organizational behavior, and leadership. His research interest focuses on nonprofit management and leadership, and human resource management. He has been the team leader of Hungarian and international projects, financed by the European Union and the Hungarian government. He holds positions of Board of Directors and Board of Trustees in for-profit- and nonprofit organizations.

Author can be contacted at farkas@ktk.pte.hu 